\title{
Variation of Thermal Time, Phyllochron and Plastochron in Passion Fruit Plants With Irrigation Depth and Hydrogel
}

\author{
Adailza G. Cavalcante ${ }^{1}$, Lourival F. Cavalcante ${ }^{2,3}$, Alian C. P. Cavalcante ${ }^{4}$, Antônio G. de L. Souto ${ }^{4}$, \\ Carlos E. M. dos Santos $^{4} \&$ Danila L. de Araújo ${ }^{4}$ \\ ${ }^{1}$ Departement of Plant Science, State University Paulista Júlio de Mesquita Filho, Jaboticabal, SP, Brazil \\ ${ }^{2}$ Departament of Agronomy, Federal University of Paraíba, Areia, PB, Brazil \\ ${ }^{3}$ INCTSal, Fortaleza, CE, Brazil \\ ${ }^{4}$ Departament of Plant Science, Federal University of Viçosa, Viçosa, MG, Brazil \\ Correspondece: Antônio G. de L. Souto, Departament of Plant Science, Federal University of Viçosa, Viçosa, \\ MG, Brazil. Tel: 55-0839-9981-7898. E-mail: gusluso@hotmail.com
}

Received: January 26, 2018

Accepted: February 28, $2018 \quad$ Online Published: April 15, 2018

doi:10.5539/jas.v10n5p229

URL: https://doi.org/10.5539/jas.v10n5p229

\begin{abstract}
The passion fruit demands water for its growth and production. Water management is relevant in regions characterized by low rainfall indices, such as semi-arid regions. In this direction, the use of hydrogel in the soil allows the water that is supplied through irrigation to be better utilized by the plants, reducing leach losses. The objective of this experiment was to evaluate the influence of hydrogel in soil cultivated with passion fruit and irrigated to various water depths on the thermal time of the phenological stages, phyllochron and plastochron of the plants. Treatments were distributed in randomized blocks in a $2 \times 5$ factorial arrangement, referring to the soil without and with hydrogel and raising the irrigation depth from $60 \%$ to $70 \%, 80 \%, 90 \%$ and $100 \%$ of crop evapotranspiration in four replications. The thermal requirements of the phenological phases and of the whole plant cycle, phyllochron of the main stem and the productive branches, and plastochron were evaluated. Increasing the irrigation depth from $60 \%$ to $100 \%$ reduced the total thermal time values from $3,811.8$ to $2,401.3{ }^{\circ} \mathrm{C}$ day and from $3,707.8$ to $2,628.7{ }^{\circ} \mathrm{C}$ day in the soil without and with hydrogel, respectively. The thermal time of the phenological phases and the phyllochron of the main stem and productive branches of the passion fruit were stimulated by an increase in irrigation depth.
\end{abstract}

Keywords: development, growth, polymer, water supplementation, Passiflora edulis

\section{Introduction}

Irrigated fruit cultivation has gained more and more space in Brazilian agriculture in the last decades, especially with respect to advances in the economy and efficiency of the use of water applied through irrigation, and in regions that present water scarcity such as the Brazilian Northeast where the cultivation of fruit trees is often restricted to the application of water to plants by irrigation (Araújo et al., 2012). In these regions, water deficiency is one of the most limiting factors to obtain economically viable productivity, and the production system depends on this supply of water to the plants for the production of fruits (Silva, Bezerra, Sousa, Pereira Filho, \& Freitas, 2011).

The passion fruit (Passiflora edulis Sims) is a fruit tree that grows, develops and produces well in tropical regions; it is the most economical species among Passifloraceae, with approximately $95 \%$ of commercial orchards in Brazil cultivated with some genotype of this species (Meletti, 2011). Passion fruit is a very demanding plant for water, requiring during most of its vegetative and productive cycle at least $10 \mathrm{~L}$ per day to meet the needs of plants with a view to fruit production (Koetz, Carvalho, Sousa, \& Souza, 2010).

Water management for this is of significant importance for increasing the production and quality of passion fruit fruits (Freire, Cavalcante, Rebequi, Dias, \& Souto, 2011), mainly in areas characterized by high evapotranspirative demand, low rainfall indices and irregular rainfall, such as the arid and semi-arid regions of the Brazilian Northeast. The adoption of irrigation water management techniques that can attenuate losses due to evaporative effects in the soil, and that contribute to greater utilization by the plants is necessary to obtain greater crop yields in those regions where water is limited, particularly for fruit species (Souza et al., 2010). 
In this context, the application of hydroabsorbent polymers appears as a management technique for reducing soil water losses, and greater use of this resource by plants. Carvalho, Cruz, and Martins (2013) explained that polymers maintain soil moisture for a longer period without compromising plant growth and production, allowing irrigation to be performed less frequently, and their use should be recommended for both rainy and irrigated conditions (Azevedo et al., 2014). Among the advantages of hydrogel in the soil, we highlight the optimization of water availability, reduction of percolation losses and nutrient leaching, improvement of aeration and soil drainage, and promotion of root and shoot growth (Fagundes, Cruz, Carvalho, Oliveira, \& Soares, 2015).

In the last 5 years, studies related to water reduction by hydrogel application have indicated satisfactory results for seedling formation, initial growth and post-plant survival of forest, coffee, olive oil and fruit species (Carvalho et al., 2013; Azevedo et al., 2014). However, according to Monteiro Neto et al. (2017), little has been demonstrated for the effects of water-borne polymers on development, or on the phenological and productive aspects of crops after the transplantation of seedlings in the field until the harvest of fruits.

When considering hydrogel's positive action in the formation of seedlings of several crops, and the scarcity of information during the growth and production of fruit, including passion fruit, it is possible that the respective input provides a viable alternative to the reduction of water application in agriculture. The objective of this experiment was to evaluate the influence of hydrogel in soil cultivated with passion fruit and irrigated to varying water depths on the accumulation of thermal time in the different phenological stages and on the speed of emission of leaves and productive branches.

\section{Material and Methods}

The experiment was carried out from September 2016 to June 2017 at Macaquinhos site, Remígio City, Paraíba State, Brazil. The climate of the region, as classified by Köppen is As (hot and humid), with rainfall from March to July (Alvares, Stape, Sentelhas, Gonçalves, \& Sparovek, 2013). Monthly average rainfall data, evaporation measured for a class ' $A$ ' tank, temperature and relative humidity of the air during the experiment are indicated in Table 1. Temperature and relative air humidity records were obtained using an HT-70 Datalogger, installed at a height of $2.5 \mathrm{~m}$ inside the orchard.

Table 1. Rainfall (R), evaporative values for a class 'A' tank (EAT), temperature (T) and relative humidity (RH) in the growing area during the experiment

\begin{tabular}{|c|c|c|c|c|c|c|c|c|}
\hline \multirow{2}{*}{ Months } & \multicolumn{4}{|c|}{2016} & \multicolumn{4}{|c|}{2017} \\
\hline & $\mathrm{R}$ & EAT & $\mathrm{T}$ & $\mathrm{RH}$ & $\mathrm{R}$ & EAT & $\mathrm{T}$ & $\mathrm{RH}$ \\
\hline & $\mathrm{mm}$ & $\mathrm{mm}$ & ${ }^{\circ} \mathrm{C}$ & $\%$ & $\mathrm{~mm}$ & $\mathrm{~mm}$ & ${ }^{\circ} \mathrm{C}$ & $\%$ \\
\hline January & 129 & 4.3 & - & - & 10 & 6.7 & 20.8 & 70.2 \\
\hline February & 33 & 5.4 & - & - & 9 & 6.8 & 21.4 & 66.4 \\
\hline March & 102 & 5.7 & - & - & 58 & 6.5 & 21.5 & 80.8 \\
\hline April & 124 & 4.3 & - & - & 54 & 4.7 & 27.0 & 81.2 \\
\hline May & 158 & 4.8 & - & - & 77 & 4.6 & 24.7 & 76.1 \\
\hline June & 33 & 4.2 & - & - & 75 & 4.5 & 22.6 & 75.3 \\
\hline July & 14 & 5.4 & - & - & - & - & - & - \\
\hline August & 8 & 6.2 & - & - & - & - & - & - \\
\hline September & 19 & 6.2 & 25.3 & 75.6 & - & - & - & - \\
\hline October & 10 & 8.2 & 26.2 & 76.2 & - & - & - & - \\
\hline November & 0 & 8.3 & 27.1 & 75.2 & - & - & - & - \\
\hline December & 103 & 7.3 & 20.7 & 77.3 & - & - & - & - \\
\hline Total/average & 733 & 5.8 & 24.8 & 76.1 & 283.0 & 5.6 & 23.0 & 75.0 \\
\hline
\end{tabular}

The soil of the experimental area was classified, according to the classification criteria of the Brazilian Soil Classification System-SiBCS (Embrapa, 2013), as Neolithic Regolithic Dystrophic. Before the start of the experiment, soil samples were collected for chemical characterization of soil fertility and texture, soil density and moisture (Embrapa, 2011), according to the results presented in Table 2. 
Table 2. Chemical and fertility attributes and soil physical properties prior to experiment setup

\begin{tabular}{ll|ll}
\hline Chemical attributes & Value & Physical attributes & Value \\
\hline $\mathrm{pH}\left(\mathrm{H}_{2} \mathrm{O}\right)$ & 7.3 & Sand $(\mathrm{mm})$ & 830 \\
$\mathrm{P}\left(\mathrm{mg} \mathrm{dm}^{-3}\right)$ & 352 & Silt $(\mathrm{mm})$ & 113 \\
$\mathrm{~K}^{+}\left(\mathrm{mg} \mathrm{dm}^{-3}\right)$ & Clay $(\mathrm{mm})$ & 57 \\
$\mathrm{Na}^{+}\left(\mathrm{cmol}_{\mathrm{c}} \mathrm{dm}^{-3}\right)$ & 1.94 & $\mathrm{CDW}\left(\mathrm{g} \mathrm{kg}^{-1}\right)$ & 25 \\
$\mathrm{H}^{+}+\mathrm{Al}^{3+}\left(\mathrm{cmol}_{\mathrm{c}} \mathrm{dm}^{-3}\right)$ & 1.90 & $\mathrm{DF}(\%)$ & 56.14 \\
$\mathrm{Al}^{3+}\left(\mathrm{cmol}_{\mathrm{c}} \mathrm{dm}^{-3}\right)$ & $\mathrm{SD}\left(\mathrm{g} \mathrm{cm}^{-3}\right)$ & 1.40 \\
$\mathrm{Ca}^{2+}\left(\mathrm{cmol}_{\mathrm{c}} \mathrm{dm}^{-3}\right)$ & 0.00 & $\mathrm{Dp}\left(\mathrm{g} \mathrm{cm}^{-3}\right)$ & 2.58 \\
$\mathrm{Mg}^{+}\left(\mathrm{cmol}_{\mathrm{c}} \mathrm{dm}^{-3}\right)$ & 6.55 & $\mathrm{TP}(\%)$ & 45.74 \\
$\mathrm{EBS}\left(\mathrm{cmol}_{\mathrm{c}} \mathrm{dm}^{-3}\right)$ & 3.98 & $\mathrm{H} \mathrm{fc}-0.010 \mathrm{MPa}\left(\mathrm{g} \mathrm{kg}^{-1}\right)$ & 107 \\
$\mathrm{CEC}\left(\mathrm{cmol}_{\mathrm{c}} \mathrm{dm}^{-3}\right)$ & 13.69 & $\mathrm{H}$ pwp $-1,500 \mathrm{MPa}\left(\mathrm{g} \mathrm{kg}^{-1}\right)$ & 58 \\
$\mathrm{~V}(\%)$ & 15.58 & Adi $\left(\mathrm{g} \mathrm{kg}^{-1}\right)$ & 49 \\
OMS $\left(\mathrm{g} \mathrm{kg}^{-1}\right)$ & 87.87 & Textural class & Free sand \\
\hline
\end{tabular}

Note. EBS $=$ exchangeable base sum $\left(\mathrm{Ca}^{2+}+\mathrm{Mg}^{2+}+\mathrm{K}^{+}+\mathrm{Na}^{+}\right) ; \mathrm{CEC}=$ cation exchange capacity $\left[\mathrm{EBS}+\left(\mathrm{H}^{+}+\right.\right.$ $\left.\left.\mathrm{Al}^{3+}\right)\right] ; \mathrm{V}=$ saturation value by exchangeable bases $(\mathrm{EBS} / \mathrm{CEC}) \times 100 ; \mathrm{MOS}=$ organic matter in substrate; CDW = clay dispersed in water; $\mathrm{DF}=$ degree of flocculation; $\mathrm{Ds}=$ soil density; $\mathrm{Dp}=$ Particles density; $\mathrm{Pt}=$ total porosity; $\mathrm{H}_{\mathrm{fc}}=$ humidity at the water level of the field capacity; $\mathrm{H}_{\mathrm{pwp}}=$ humidity at the water energy level at the permanent wilting point; $\mathrm{MPa}=$ mega Pascal; $\mathrm{Wa}=$ Water available $\left(\mathrm{H}_{\mathrm{fc}}-\mathrm{H}_{\mathrm{pwp}}\right) ; \mathrm{P}=$ phosphorus - Mehlich-1; $\mathrm{K}$ $=$ Potassium - Mehlich $-1 ; \mathrm{Na}^{+}=$sodium $-\mathrm{KCl} 1 \mathrm{~mol} / \mathrm{L} ; \mathrm{Ca}^{2+}=$ calcium $-\mathrm{KCl} 1 \mathrm{~mol} / \mathrm{L} ; \mathrm{Mg}^{2+}=$ magnesium $\mathrm{KCl} 1 \mathrm{~mol} / \mathrm{L} ; \mathrm{H}^{+}+\mathrm{Al}^{3+}=$ potential acidity - calcium acetate $0.5 \mathrm{~mol} / \mathrm{L}-\mathrm{pH} 7.0 ; \mathrm{Al}^{3+}=$ exchangeable aluminum - calcium acetate $0.5 \mathrm{~mol} / \mathrm{L}-\mathrm{pH} 7.0$.

The treatments were distributed in randomized blocks with a $2 \times 5$ factorial arrangement, relative to the soil without and with hydrogel, and irrigation depths of $60 \%, 70 \%, 80 \%, 90 \%$ and $100 \%$ of crop evapotranspiration (CET) in four replications. Each experimental unit was represented by one plant, with $3 \mathrm{~m}$ of space between plants and $3 \mathrm{~m}$ between rows; the experiment was conducted in a pressure lysimeter $60 \mathrm{~cm}$ in diameter and 50 $\mathrm{cm}$ in height with an area of $0.28 \mathrm{~m}^{2}$ and a volume of $120 \mathrm{dm}^{3}$, using $100 \mathrm{dm}^{3}$ of soil corresponding to $140 \mathrm{~kg}$ of substrate.

The hydroabsorbent polymer was purchased from Hydroplan EB/HyArogrogel and had the following physical properties: appearance - white granules, particle size -0.5 to $3 \mathrm{~mm}$; anionic, active ingredient (\% solids content) -100 , water content $(\%)-10$, volume density $\left(\mathrm{g} \mathrm{cm}^{-3}\right)-0.8$ and solubility - insoluble in water. The hydrogel was applied at a dose of $1 \mathrm{~g} \mathrm{~kg}^{-1}$ of soil to sandy textured soil, as recommended by the manufacturer, at four stations, one in each quadrant of the lysimeter, $10 \mathrm{~cm}$ from the wall, $20 \mathrm{~cm}$ from the stem of the plant and at a depth of $20 \mathrm{~cm}$. Each station was opened with a diameter of $5 \mathrm{~cm}$, and the respective volume of substrate was mixed with a quarter of the total of $140 \mathrm{~g}$ of the polymer (hydrogel + substrate) and then packed into the station. The seeds of passion fruit cv. Guinezinho were obtained from fruits of a commercial orchard of plants submitted to mass selection, of the local variety that is traditionally grown in the municipality of Nova Floresta city, Paraíba State, Brazil.

One day before transplantation, the soil moisture of all lysimeters was raised to the field capacity level. This practice consisted of applying a volume of water at the beginning of drainage and measuring the volume applied and drained after $24 \mathrm{~h}$; humidity at the field capacity level was determined by the difference between the volume applied and the volume drained (Freire et al., 2011). The seedlings were transplanted 1 day after determination of the field capacity of the lysimeter, and the irrigations were carried out with a frequency of 2 days. The whole experiment with irrigation depths of $60 \%, 70 \%, 80 \%, 90 \%$ and $100 \%$ of CET, respectively, corresponded to application of 492.1, 574.1; 656.1; 738.1 and 820.1 L plant ${ }^{-1}$ during the conduction of the experiment.

Irrigation of the plants was done manually, taking as reference the CET obtained from evaporation for a class ' $\mathrm{A}$ ' tank. The following coefficients of cultivation (kc) were adopted as proposed by Freire et al. (2011): 0.40 from transplantation to pruning of the main stem; 0.64 from pruning of the stem up to 90 days after transplantation (DAT); 0.96 from 90 to 120 DAT; and 1.2 from 120 DAT until the end of the harvest. CET was obtained as the product of potential evapotranspiration $\left(\mathrm{ET}_{0}\right)$ and the crop coefficient $(\mathrm{kc})$ : $\mathrm{CET}=\mathrm{ET}_{0} \times \mathrm{kc}$. Potential evapotranspiration was estimated via the product of evaporation from a class ' $\mathrm{A}$ ' tank $\left(\mathrm{ET}_{\mathrm{a}}\right)$ and the correction 
factor of $0.75\left(\mathrm{ET}_{0}=\mathrm{ET}_{\mathrm{a}} \times 0.75\right)$, according to methodology described by Sousa Marouelli, Coelho, Pinto and Coelho Filho (2011).

Transplantation was done with standard seedlings with a height of $20 \mathrm{~cm}$ and three pairs of leaves. Plants were supported using a simple espalier made from no. 12 smooth wire, installed at a height of $2.7 \mathrm{~m}$ on the top of the piles. Plants grew on a single stem until reaching the supporting wire at the moment of pruning the apical bud 10 $\mathrm{cm}$ above the espalier, to stimulate the emission and growth of secondary branches, one in an easterly direction and the other in a westerly direction (Freire et al., 2011). Nitrogen (urea $-45 \% \mathrm{~N}$ ) and potassium (potassium chloride $-60 \% \mathrm{~K}_{2} \mathrm{O}$ ) fertilization was carried out monthly from 30 DAT, at an $\mathrm{N}: \mathrm{K}$ ratio of $1: 1$, applying 5,10 and $15 \mathrm{~g}$ of $\mathrm{N}$ and $\mathrm{K}$, at 60,90 and 120 DAT. From 150 DAT until the end of the harvest, $20 \mathrm{~g}$ of $\mathrm{N}$ and $20 \mathrm{~g}$ of K was applied. Phosphate fertilization was carried out by applying $5 \mathrm{~g} \mathrm{plant}^{-1}$ of a single superphosphate (18\% $\mathrm{P}_{2} \mathrm{O}_{5}, 20 \% \mathrm{Ca}$ and $12 \% \mathrm{~S}$ ) from 60 DAT, every 2 months until fruit harvesting.

In the experimental area, an HT-70 Datalogger was installed at a height of $2.5 \mathrm{~m}$ from the soil to record the daily air temperature, to estimate the daily and accumulated thermal time, both in degree days, for the whole cycle and for the phenological phases of the passion fruit culture. From transplantation of the seedlings to the field, the daily thermal time (TTd) was determined, according to the methodology proposed by Arnolds (1960), as presented in Equation 1. The base temperature used in this experiment for the whole passion fruit cycle was $8{ }^{\circ} \mathrm{C}$, as reported by Souza et al. (2010) for passion fruit.

$$
T T d=[(\operatorname{Tmax}+\operatorname{Tmin} / 2)-T b] \times \text { Day }
$$

where, Tmax: maximum air temperature $\left({ }^{\circ} \mathrm{C}\right)$; Tmin: minimum air temperature $\left({ }^{\circ} \mathrm{C}\right) ; \mathrm{Tb}=$ base temperature $\left({ }^{\circ} \mathrm{C}\right)$.

The accumulated thermal time (TTa) of the entire crop cycle and of the phenological phases was obtained by summing the daily thermal time required to reach the phenological phase under evaluation, according to Equation 2:

$$
T T a=\sum_{i=1}^{n} T T d
$$

where, $\mathrm{n}$ is the number of days to complete all or part of the passion fruit phenological cycle.

The phenological phases were defined considering the appearance of specific organs distinguishable with the naked eye, which has the advantages of simplicity and easy identification in the field and defines the beginning and end of the phenological phase of a given culture (Streck, Bosco, Michelon, Walter, \& Marcolin, 2006). Phenological phases or development subperiods were divided into: transplantation of seedlings to pruning of the main stem (TS-PMS), pruning of the main stem to pruning of secondary branches (PMS-PSB), pruning of secondary branches to the emission of flower buds (PSB-EFB), floral bud emission to fruit fertilization (EFB-FF), and fruit fertilization to fruit maturity (FF-FM).

From transplantation, the number of leaves on the main stem was counted every fortnight until pruning of the apical meristem and the beginning of emission of lateral branches at the beginning of fruiting, respectively, to calculate the phyllochron of the main stem and the secondary branches $\left({ }^{\circ} \mathrm{C}\right.$ day $\left.{ }^{1 e a f^{1}}\right)$. From pruning of the lateral branches until the beginning of fruiting, and for the same evaluation period for the phyllochron of the secondary branches, the number of branches emitted by the secondary branches of the plants was recorded, to determine the plastochron $\left({ }^{\circ} \mathrm{C}\right.$ day branch $\left.^{-1}\right)$. From these data, linear regressions were established between the number of leaves (NL) and number of branches (NB), respectively, with TTa, for each evaluation. The values of phyllochron and plastochron consisted of the value of the inverse relationship of the coefficient of linear regression generated between NL and TTa (phyllochron) and NB and TT (plastochron), as also used by Martins, Reis, and Pinheiro (2012), and Martins, Radons, Streck, Knies, and Carlesso (2011), respectively.

The data were submitted to analysis of variance by F-test at $5 \%$ probability; the means referring to the absence and presence of the hydrogel were compared by F-test, which in this case is conclusive for two values of the same factor, and the mean values for regression irrigation depths $(p<0.05)$. For the statistical analysis and processing of the data, SAS/STAT statistical software was used.

\section{Results and Discussion}

From analysis of variance (Table 3), it was verified that the interaction hydrogel $\times$ irrigation depth exerts a significant influence on the thermal time of the subperiod corresponding to fertilization of the flower to the point of maturation of the fruit, on the whole crop cycle, and on the speed of leaf issue on the main stem and secondary branches (phyllochron). The isolated sources of variation (hydrogel and irrigation depth) interfered in the thermal time of the subperiods of pruning of the main stem to pruning of secondary branches and of emission of floral buds to fertilization of the flowers. The accumulated thermal time for the subperiods related to 
transplantation of the seedlings to pruning of the main branch and to pruning of the secondary branches to flower bud emission was not influenced by application of the treatments, presenting average values of 699.50 and $945.75{ }^{\circ} \mathrm{C}$ day TTa, respectively. A similar trend was observed for the plastochron variable, which did not respond to application of the sources of variation or to the interaction between them, requiring an average thermal accumulation of $30.12^{\circ} \mathrm{C}$ day for the emission of a productive branch.

Table 3. Summary of analysis of variance, by the mean table, related to the variables of thermal time from transplantation to pruning of the main stem (TS-PMS), from pruning of the main stem to pruning of secondary branches (PMS-PSB), from pruning of secondary branches to the emission of flower buds (PSB-EFB), from floral bud emission to fruit fertilization (EFB-FF) and from fruit fertilization to fruit maturity (FF-FM), and related to total thermal time (TTT), phyllochron of the fruit (FPS), phyllochron of the secondary branches (FSB) and plastochron (PTC) of irrigated plants with varying irrigation depth (D) in soil without and with hydrogel (H)

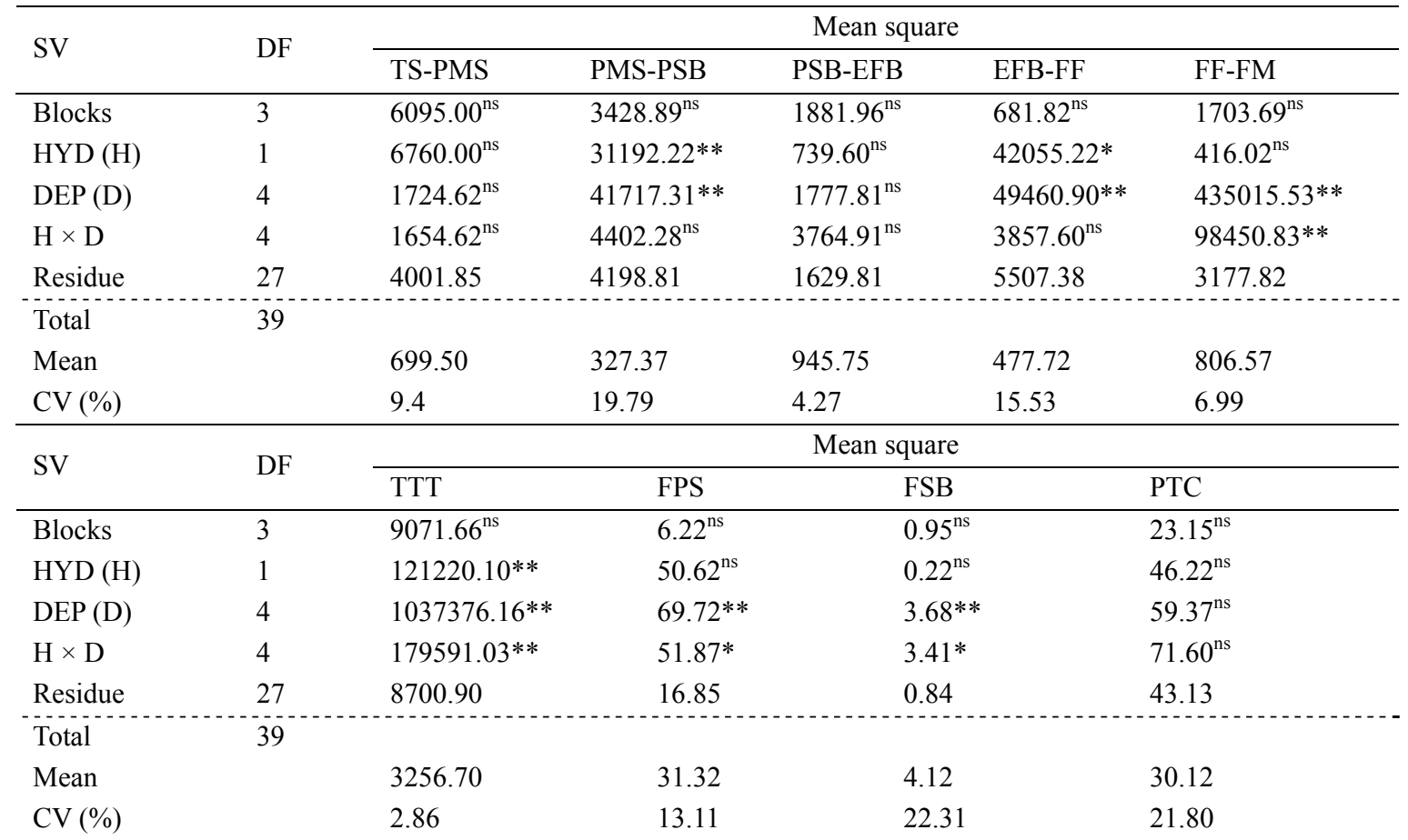

Note. $\mathrm{SV}=$ source of variation; $\mathrm{DF}=$ degrees of freedom; $\mathrm{CV}=$ coefficient of variation; $* *$ and $*=$ significant at $1 \%$ and $5 \%$ probability, respectively; ${ }^{\mathrm{ns}}=$ not significant at $1 \%$ and $5 \%$ probability.

The accumulated thermal time required to complete the subperiod corresponding to pruning of the main stem to pruning of the secondary branches was linearly reduced to the level of $4.2{ }^{\circ} \mathrm{C}$ per unit increment of irrigation depth (Figure 1A). An increase in water application from $60 \%$ to $100 \%$ of the evapotranspiration requirement of the crop reduced the thermal time of the subperiod or phenological phase from 420.03 to $250.83{ }^{\circ} \mathrm{C}$ day; that is, water supply adequate for the requirements of passion fruit plants decreased by $40 \%$ the time required to complete the phenological phase of PMS-PSB. Similarly, it was observed that the need for thermal units was reduced by $4.2{ }^{\circ} \mathrm{C}$ per unit increment of irrigation (Figure 1C). When comparing the lowest and highest water depths, the TTa of EFB-FF was reduced from 580.54 to $410.66{ }^{\circ} \mathrm{C}$ day, verifying that adequate water supply promotes greater growth stimulus of floral buds and, consequently, anthesis and fertilization of passion fruit flowers.

The stimulus in growth evidences the reduction in time or precocity of the plants to complete the development subperiods (Figures 1A and 1C). It is the main external factor stimulating the photosynthetic processes that allow plants to not suffer inhibition in growth and development, contributing to greater elongation, cell division and maintenance of leaf turgescence (Taiz, Zeiger, Møller, \& Murphy, 2017). Under these conditions, plants use the nutrients and reserves vital for the synthesis and translocation of photoassimilates to new growth areas more efficiently (Yang, Qu, \& Zhang 2012). 
On the other hand, under water deficit, as shown in the $60 \%$ CET slide, carbon assimilation in the plant is inhibited due to limitation in the diffusion of $\mathrm{CO}_{2}$ by a reduction of the stomatal opening that compromises the photosynthetic activity and growth of the plant (Zlatev \& Lidon; 2012). In response, plants fail to invest in growth processes (cell division and elongation) and allocate non-photosynthetic organisms to the formation of defense molecules or biochemical changes in leaves, to reduce photosynthesis and prevent damage (Muller et al., 2011).

The thermal time of the phenological phases related to pruning of the main stem to pruning of the secondary branches (Figure 1B) and to emission of floral buds to flower fertilization (Figure 1D) was reduced with application of hydrogel, indicating that the soil was more moist for longer, as verified also by Mendonça, Urbano, Peres, and Souza (2013). The polymer stimulated the growth and development of passion fruit, revealing a need for thermal units of 7.9 and $12.7 \%$ lower for the phenological phases related to the periods of PMS-PSB and EFB-FF, respectively, compared to plants that were not treated with hydrogel.

This growth stimulus, in a shorter period, could be a response to the improvement of physical properties, such as soil structure and aeration and hydric properties such as moisture and storage of hydroabsorbent polymer water in the plants, resulting in better plant development (Azevedo et al., 2014; Fagundes et al., 2015), as observed in the initial growth of passion fruit seedlings (Carvalho et al., 2013). Hydroabsorbent polymers are preferentially indicated for regions with low water availability or long periods of drought, as has been occurring in recent years in the semi-arid regions of the Brazilian Northeast where the soil is low in moisture and reflects negatively on the growth and development of plants (Monteiro Neto et al., 2017).
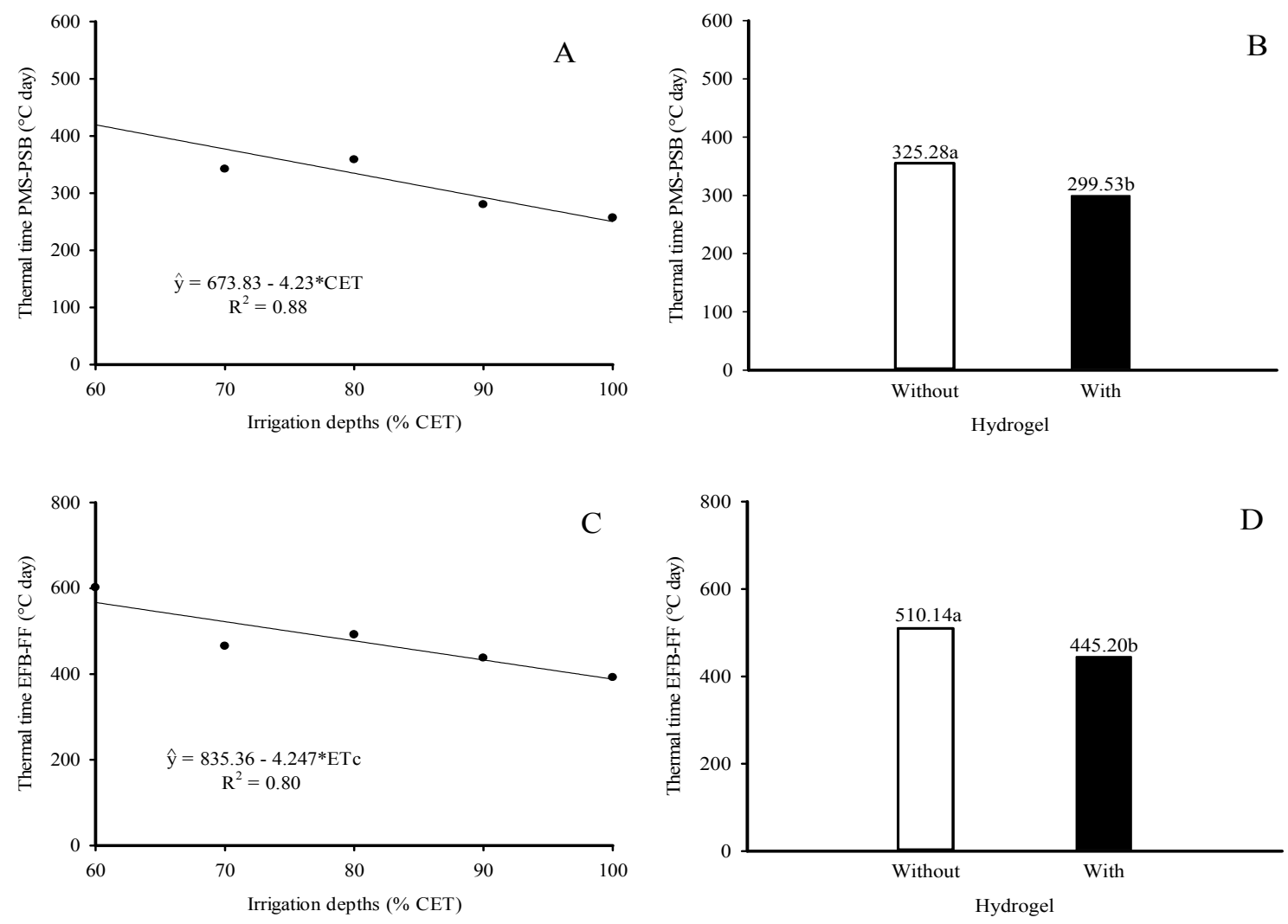

Figure 1. Thermal time accumulation of passion fruit plants in relation to the subperiods of pruning the main stem to pruning of secondary branches (PMS-PSB) and of issuance of floral buds to flower fertilization (EFB-FF) as a function of irrigation depth (A) and (C), for the substrate without and with hydrogel (B) and (D). Means followed by the same letter do not differ from each other by F-test at 5\% probability

The thermal time to complete the phenological phase related to fertilization of the flowers to the point of maturation of the fruit was initially reduced with an increase in the irrigation water depth (Figure 2A). TTa decline with increasing irrigation depth occurred from $60 \%$ to $85.6 \%$ and $83.5 \%$ f CET, reaching the lowest 
values of 499.5 and $602.2{ }^{\circ} \mathrm{C}$ day in the soil without and with hydrogel, respectively; on the other hand, irrigation at depths above the minimum estimates elevated the thermal time of the phenological phase and inhibited growth of the fruit, consequently delaying the harvest.

When evaluating the thermal time relative to fruit fertilization to maturation of the passion fruit in Londrina, Paraná, Neves, Carvalho, and Neves (1999) found that for the complete phenological phase (FF-FM), the plants require thermal accumulation of 861.7 to $867.6^{\circ} \mathrm{C}$ day. In other fruit trees, variability in the thermal requirement for the phenological interval FF-FM has been observed, as verified in cashew nuts (Anacardium occidentale cv. FAGA 1) cultured in Mato Grosso, Brazil, that require, on average, $437.3{ }^{\circ} \mathrm{C}$ day (Matos et al., 2014); Rodrigues, Souza, and Lima (2013), evaluating the period from opening of flowers to the point of harvest for mango fruits (Mangifera indica cv. Tommy Atkins), registered a thermal requirement of $862.21{ }^{\circ} \mathrm{C}$ day which is, therefore, superior to that for passion fruit.

The thermal time of the whole plant development cycle was linearly reduced from 29.58 to $19.58{ }^{\circ} \mathrm{C}$ day, in the soil without and with hydrogel, respectively, for each increment of irrigation depth (Figure 2B). When comparing the results of irrigation depth from $60 \%$ to $100 \%$ CET, total thermal time values decreased from $3,811.8$ to $2,401.3{ }^{\circ} \mathrm{C}$ day and from $3,707.8$ to $2,628.7^{\circ} \mathrm{C}$ day, respectively, in the soil without and with hydrogel This higher requirement of thermal units and longer duration for the plant to complete part or all of the development cycle, especially at $60 \%$ CET depth, is a result of the water deficit that causes an imbalance between the water available in the soil and the evapotranspirative rate of the plant. This situation naturally occurs in the field, impairing cell division and assimilation and accumulation of carbon, and reducing plant tissue expansion (Tardieu, Granier, \& Muller, 2011).

The results for treatment of the plants irrigated with $100 \%$ CET are consistent with those of Souza, Chig, Costa, Lenza, and Campelo Júnior (2010) for passion fruit (P. edulis) irrigated in Mato Grosso, Brazil, where the plants required close to 2,500 thermal units for the crop to complete the cycle. This information shows that the thermal time is inherent to each species and serves as a reliable measure of the plant's biological time (Schmidt et al., 2017).
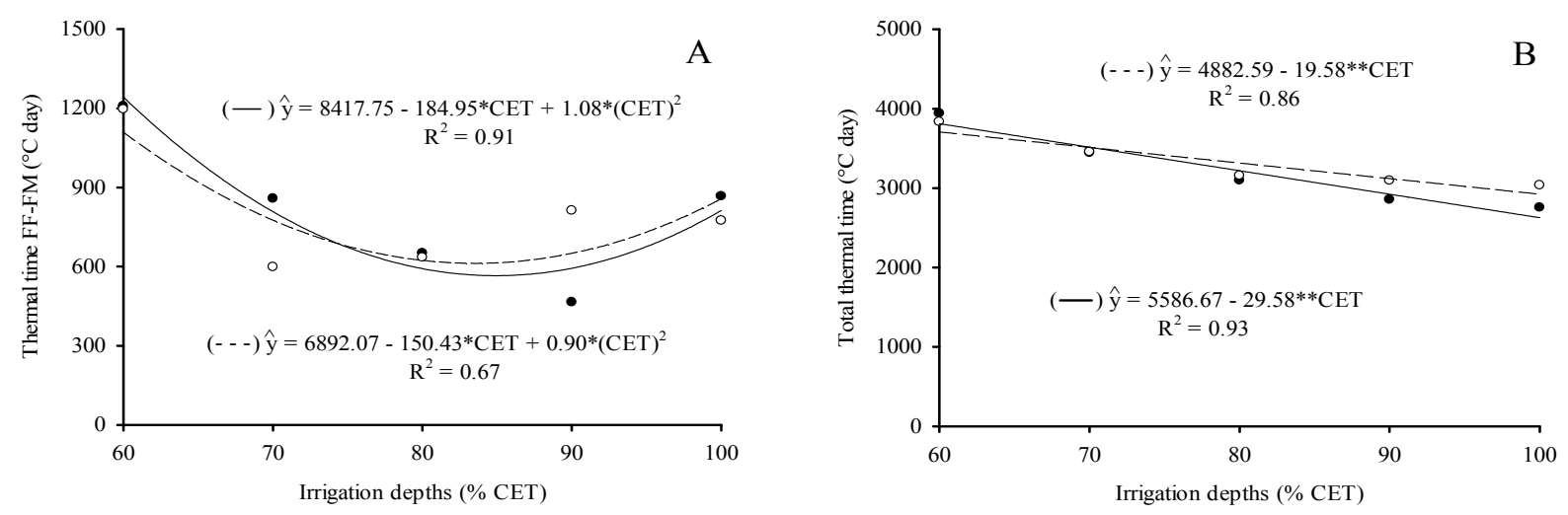

Figure 2. Thermal time accumulation of passion fruit plants from the development subperiod of the fruit to the fruit maturity point [FF-FM] (A), and total thermal time (B) as a function of soil irrigation layers without (-) and with (- - ) hydrogel

An increase in soil irrigation depth without hydrogel linearly retarded leaf emission (phyllochron) on the main stem of passion fruit plants at $0.185{ }^{\circ} \mathrm{C}$ leaf ${ }^{-1}$ per unit increase of CET (Figure 3A). From the numerical relationship between the phyllochron values of 33.93 and $26.53{ }^{\circ} \mathrm{C}$ day leaf ${ }^{-1}$, there was a reduction of $27.9 \%$ between the plants irrigated with water depths of $60 \%$ and $100 \%$ CET, but plants irrigated at $100 \%$ CET had a lower thermal time requirement and, therefore, faster leaf emission. In the hydrogel treatments, the phyllochron was elevated up to a maximum estimated irrigation depth of $82.1 \% \mathrm{CET}$, with a phyllochron value of $38.9{ }^{\circ} \mathrm{C}$ day leaf ${ }^{1}$, indicating that the input was delayed up to the maximum estimated emission of leaves by the plants.

Variation in the phyllochron of the secondary branches of plants in the non-hydrogel treatments with increased irrigation water depth did not fit any regression model, presenting a mean phyllochron value of $3.99{ }^{\circ} \mathrm{C}$ day leaf ${ }^{1}$ (Figure 3B). In the soil with hydrogel, an increase in irrigation depth from $60 \%$ to $100 \%$ of the 
evapotranspiratory requirement of the passion fruit reduced the need for thermal units from 6.86 to $4.06{ }^{\circ} \mathrm{C}$ day for emission of leaves on the secondary branches of the plants. The mechanisms of plant response to soil water deficit include stomatal closure, loss of photosynthetic activity, inhibition of leaf formation and acceleration of leaf senescence and abscission, as occurred with the phyllochron of passion fruit plants irrigated at $60 \% \mathrm{CET}$ (Figure 3) (Taiz et al., 2017).

When comparing the phyllochron values of the main stem (Figure 3A) with those of the secondary branches (Figure 3B), it is observed that the leaf emission rate of the secondary branches is almost six times faster than that of the main stem; this behavior must be associated with the greater contribution of leaves and leaf area that promotes greater interception of sunlight, influx and assimilation of carbon, photosynthetic activity, growth and differentiation of tissues (Muller et al., 2011; Taiz et al., 2017) of the leaves of secondary branches. These results contradict those presented by Maldaner et al. (2009) who found that the phyllochron of the main stem of secondary branches in eggplant plants (Solanum melongena L.) showed no differences in thermal time during leaf emission.
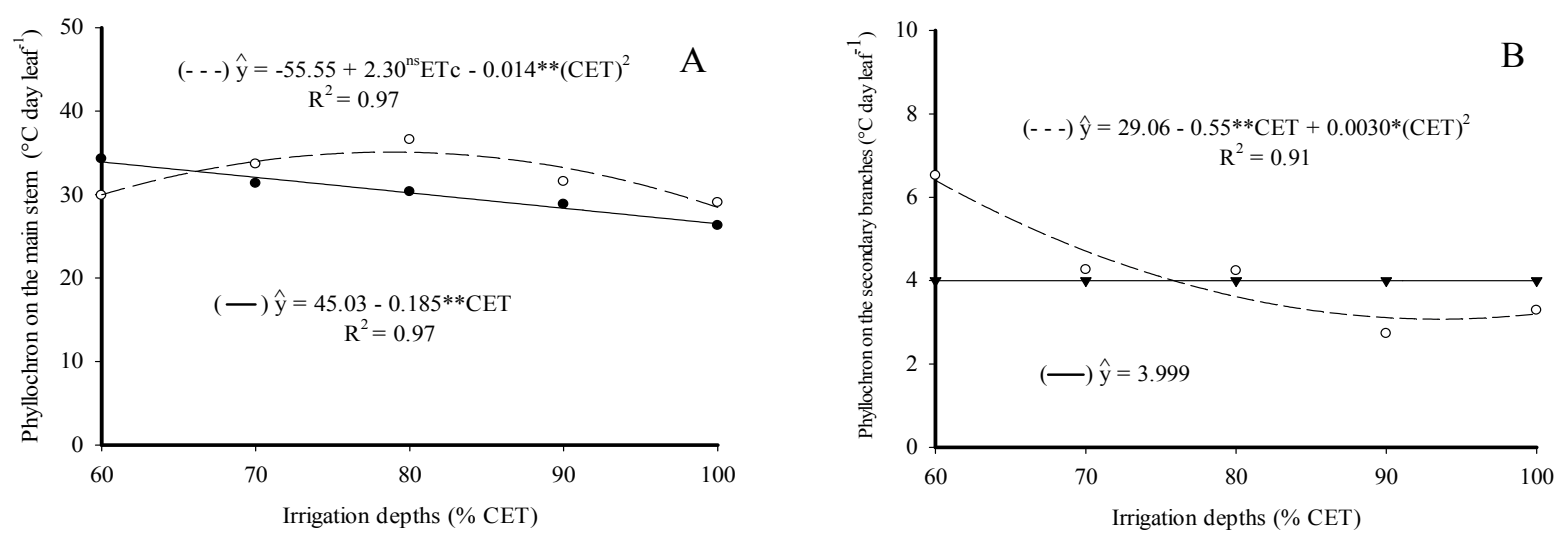

Figure 3. Phyllochron of the main stem (A) and secondary branches (B) of passion fruit plants irrigated to varying depths, in soil without (-) and with (- - -) hydrogel

From the mean values of the thermal time accumulated in each phenological phase evaluated (Table 3), a figure was created demonstrating the thermal time to complete each phenological phase of the passion fruit crop cycle (Figure 4). Among the phenological phases evaluated, the smallest and greatest need for thermal units corresponded respectively to the intervals between pruning of the main stem and pruning of secondary branches (PMS-PSB) and between secondary branch pruning and the emission of floral buds (PSB-EFB). In general, the thermal time of the phenological phases obeyed the order: from pruning of secondary branches to emission of floral buds $(\mathrm{PBS}-\mathrm{EFB})>$ from flower fertilization to fruit maturity $(\mathrm{FF}-\mathrm{FM})>$ from transplantation of seedlings to pruning of the main stem $($ TS-PMS) $>$ from emission of floral buds to flower fertilization $(\mathrm{EFB}-\mathrm{FF})>$ from pruning of the main stem to pruning of secondary branches (PMS-PSB).

Monitoring of the heat requirement in fruit plants is widely used to estimate the time required to complete part or all of the development cycle of the crop, and represents the daily accumulation of energy required to stimulate plant growth. It is, therefore, an important parameter in decision-making and crop management factors such as planting, harvesting and cultural treatments, and in indicating the climatic potential of the species for commercial exploitation (Rodrigues et al., 2013; Matos et al., 2014). 


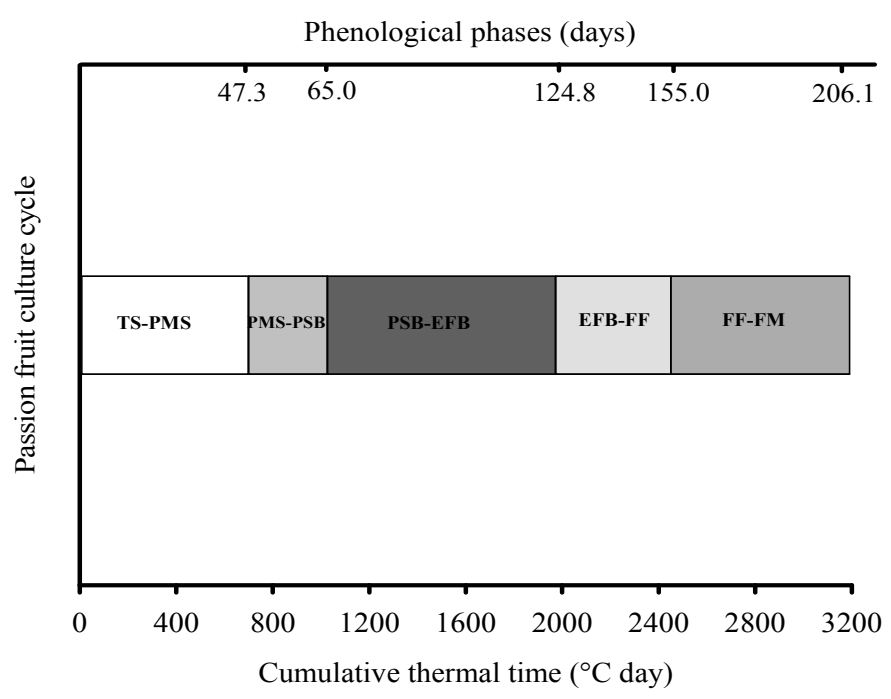

Figure 4. Thermal time and mean age in each phenological phase of passion fruit plants grown in the State of Paraíba

\section{Conclusion}

Increasing irrigation depth from $60 \%$ to $100 \%$ CET reduces the thermal time for phenological phases and stimulates leaf emission on the main stem and secondary branches of passion fruit.

The application of hydrogel as a form of water retention in the soil reduces the thermal time for the development subperiods of pruning of the main stem to pruning of secondary branches and of emission of floral buds to fertilization of the flowers.

The thermal need of each phenological phase of passion fruit follows the order: from pruning of the secondary branches to emission of floral buds (PBS-EFB) $>$ from fruit fertilization to fruit maturity (FF-FM) $>$ from transplantation of seedlings to pruning of the main stem (TS-PMS) $>$ from emission of floral buds to flower fertilization (EFB-FF) > from pruning of the main stem to pruning of secondary branches (PMS-PSB).

\section{Acknowledgments}

To the Instituto Nacional de Ciência e Tecnologia em Salinidade (INCTSal) and to the Conselho Nacional de Desenvolvimento Científico e Tecnológico (CNPq) for the financial support and the granting of scholarship to the first author.

\section{References}

Alvares, C. A., Stape, J. L., Sentelhas, P. C., Gonçalves, J. L. M., \& Sparovek, G. (2013). Koppen's climate classification map for Brasil. Meteorologische Zeitschrift, 22(6), 711-728. https://doi.org/10.1127/0941-29 48/2013/0507

Araújo, H. F., Costa, R. N. T., Crisóstomo, J. R., Saunders, L. C. U., Moreira, O. C., \& Macedo, A. B. M. (2012). Produtividade e análise de indicadores técnicos do maracujazeiro-amarelo irrigado em diferentes horários. Revista Brasileira de Engenharia Agrícola e Ambiental, 16(2), 159-164. https://doi.org/10.1590/S1415-436 62012000200005

Arnold, C. Y. (1960). Maximum-Minimum temperature as a basis for computing heat units. Proceedings of the American Society for Horticultural Science, 76(1), 682-692.

Azevedo, J. M. G., Reis, E. F., Tomaz, M. A., Garcia, G. O., Nogueira, N. O., \& Dardengo, M. C. J. D. (2014). Índices de qualidade e crescimento de mudas de café Conilon sob irrigação e hidrorretentor. Revista Brasileira de Ciências Agrárias, 9(3), 432-439. https://doi.org/10.5039/agraria.v9i3a3310

Carvalho, R. P., Cruz, M. C. M., \& Martins, L. M. (2013). Frequência de irrigação utilizando polímero hidroabsorvente na produção de mudas de maracujazeiro amarelo. Revista Brasileira de Fruticultura, 35(2), 518-526. https://doi.org/10.1590/S0100-29452013000200022 
Embrapa (Empresa Brasileira de Pesquisa Agropecuária). (2011). Solos: Sistema Brasileiro de Classificação de Solo ( $3^{\text {a }}$ ed). Rio de Janeiro, RJ: Embrapa Solos.

Embrapa (Empresa Brasileira de Pesquisa Agropecuária). (2013). Manual de análises químicas de solos, plantas e fertilizantes. Brasília, DF: Embrapa Solos.

Fagundes, M. C. P., Cruz, M. C. M., Carvalho, R. P., Oliveira, J., \& Soares, B. C. (2015). Polímero hidroabsorvente na redução de nutrientes lixiviados durante a produção de mudas de maracujazeiro amarelo. Revista Caatinga, 28(1), 121-129.

Freire, J. L. O., Cavalcante, L. F., Rebequi, A. M., Dias, T. J., \& Souto, A. G. L. (2011). Necessidade hídrica do maracujazeiro amarelo cultivado sob estresse salino, biofertilização e cobertura do solo. Revista Caatinga, 24(1), 82-91.

Koetz, M., Carvalho, J. A., Sousa, A. M. G., \& Souza, K. J. (2010). Qualidade de frutos do maracujazeiro-amarelo em ambiente protegido e natural produzidos sob diferentes regimes de irrigação. Revista Brasileira de Agricultura Irrigada, 4(2), 115-126. https://doi.org/10.7127/RBAI.V4N200026

Maldaner, I. C., Guse, F. I., Streck, N. A., Heldwein, A. B., Lucas, D. D. P., \& Loose, L. H. (2009). Filocrono, área foliar e produtividade de frutos de berinjela conduzidas com uma e duas hastes por planta em estufa plástica. Ciência Rural, 39(3), 671-677. https://doi.org/10.1590/S0103-84782009005000013

Martins, F. B., Reis, D. F., \& Pinheiro, M. V. M. (2012). Base temperature and phyllochron in two olive cultivars. Ciência Rural, Santa Maria, 42(11), 1975-1981. https://doi.org/10.1590/S0103-84782012001100011

Martins, J. D., Radons, S. Z., Streck, N. A., Knies, A. E., \& Carlesso, R. (2011). Plastocrono e número final de nós de cultivares de soja em função da época de semeadura. Ciência Rural, 41(6), 954-959. https://doi.org/ $10.1590 / \mathrm{S} 0103-84782011005000064$

Matos, V. A. T., Pivetta, F., Paiva Sobrinho, S., Tissiani, A. S. O., Pereira, A. P. M. S., Ramos, F. T., \& Campelo Júnior, J. H. (2014). Temperaturas basais e exigência térmica para a maturação de caju. Bioscience Journal, 30(4), 969-977.

Medeiros, S. A. S., Cavalcante, L. F., Bezerra, M. A. F., Nascimento, J. A. M., Bezerra, F. T. C., \& Prazeres, S. S. (2016). Água salina e biofertilizante de esterco bovino na formação e qualidade de mudas de maracujazeiro amarelo. Irriga, 21(4), 779-795. https://doi.org/10.15809/irriga.2016v21n4p779-795

Meletti, L. M. M. (2011). Avanços na cultura do maracujá no Brasil. Revista Brasileira de Fruticultura, 33(Special), 83-91. https://doi.org/10.1590/S0100-29452011000500012

Mendonça, T. G., Urbano, V. R., Peres, J. G., \& Souza, C. F. (2013). Hidrogel como alternativa no aumento da capacidade de armazenamento de água no solo. Water Resources and Irrigation Management, 2(2), 87-92.

Monteiro Neto, J. L. L., Araújo, W. F., Chagas, E. A., Siqueira, R. H. S., Oliveira, G. A., \& Abanto-Rodriguez, C. (2017). Hydrogels in Brazilian Agriculture. Revista Agroambiente On-line, 11(4), 347-360. https://doi.org/ 10.18227/1982-8470ragro.v11i4.4130

Muller, B., Pantin, F., Génard, M., Turc, O., Freixes, S., Piques, M., \& Gibon, Y. (2011). Water deficits uncouple growth from photosynthesis, increase $\mathrm{C}$ content, and modify the relationships between $\mathrm{C}$ and growth in sink organs. Journal of Experimental Botany, 62(6), 1715-1729. https://doi.org/10.1093/jxb/erq438

Neves, C. S. V. J., Carvalho, S. L. C., \& Neves, P. M. O. J. (1999). Porcentagem de frutificação, período de desenvolvimento dos frutos e unidades térmicas para maracujá amarelo. Revista Brasileira de Fruticultura, 21(2), 128-130.

Rodrigues, J. C., Souza, P. J. O. P., \& Lima, R. T. (2013). Estimativa de temperaturas basais e exigência térmica em mangueiras no nordeste do estado do Pará. Revista Brasileira de Fruticultura, 35(1), 143-150. https://doi.org/10.1590/S0100-29452013000100017

Schmidt, D., Zamban, D. T., Prochnow, D., Caron, B. O., Souza, V. Q., Paula, G. M., \& Cocco, C. (2017). Caracterização fenológica, filocrono e requerimento térmico de tomateiro italiano em dois ciclos de cultivo. Horticultura Brasileira, 35(1), 89-96. https://doi.org/10.1590/s0102-053620170114

Silva, A. R. A., Bezerra, F. M. L., Sousa, C. C. M., Pereira Filho, J. V., \& Freitas, C. A. S. (2011). Desempenho de cultivares de girassol sob diferentes lâminas de irrigação no Vale do Curu, CE. Revista Ciência Agronômica, 42(1), 57-64, 2011. https://doi.org/10.1590/S1806-66902011000100008 
Sousa, V. F., Marouelli, W. A., Coelho, E. F., Pinto J. M., \& Coelho Filho, M. C. (2011). Irrigação e fertirrigação em fruteiras e hortaliças. Brasília, DF: Embrapa Informação Tecnológica.

Souza, F. E. F., Chig, L. A., Costa, R. A. H. M., Lenza, J. B., \& Campelo Junior, J. H. (2010). Relação entre acúmulo de graus-dia e de unidades fototérmicas e crescimento vegetativo do maracujazeiro roxo (Passiflora edulis Sims). Uniciências, 14(1), 39-51. https://doi.org/10.17921/1415-5141.2010v14n1p\%25p

Streck, N. A., Bosco, L. C., Michelon, S., Walter, L. C., \& Marcolin, E. (2006). Duração do ciclo de desenvolvimento de cultivares de arroz em função da emissão de folhas no colmo principal. Ciência Rural, 36(4), 1086-1093. https://doi.org/10.1590/S0103-84782006000400007

Taiz, L., Zeiger, E., Møller, I. M., \& Murphy, A. (2017). Fisiologia e Desenvolvimento Vegetal (6th ed.). Porto Alegre, RS: Artmed.

Tardieu, F., Granier, C., \& Muller, B. (2011). Water deficit and growth. Co-ordinating processes without an orchestrator? Current Opinion in Plant Biology, 14(3), 283-289. https://doi.org/10.1016/j.pbi.2011.02.002

Yang, L., Qu, H., Zhang, Y., \& Li, F. (2012). Effects of partial root-zone irrigation on physiology, fruit yield and quality and water use efficiency of tomato under different calcium levels. Agricultural Water Management, 104(1), 89-94. https://doi.org/10.1016/j.agwat.2011.12.001

Zlatev, Z., \& Lidon, F. C. (2012). An overview on drought induced changes in plant growth, water relations and photosynthesis. Emirates Journal of Food and Agriculture, 24(1), 57-72. https://doi.org/10.9755/ ejfa.v24i1.10599

\section{Copyrights}

Copyright for this article is retained by the author(s), with first publication rights granted to the journal.

This is an open-access article distributed under the terms and conditions of the Creative Commons Attribution license (http://creativecommons.org/licenses/by/4.0/). 